\title{
APPLICATION OF PRECISION AGRICULTURE TECHNOLOGY IN PODLASKIE VOIVODESHIP
}

\author{
Andrzej Borusiewicz ${ }^{\mathrm{a}^{*}}$, Krzysztof Kapela $^{\mathrm{b}}$, Paulina Drożyner ${ }^{\mathrm{c}}$, Tomasz Marczuk ${ }^{\mathrm{a}}$ \\ ${ }^{a}$ Department of Agronomy, The Academy of Agrobusiness in Łomza \\ ${ }^{\mathrm{b}}$ Department of Agronomy, Siedlce University of Natural Sciences and Humanities \\ ${ }^{\mathrm{c}}$ Department of Safety Foundations, University of Warmia and Mazury in Olsztyn \\ *Corresponding author: e-mail: andrzej.borusiewicz@wsa.edu.pl
}

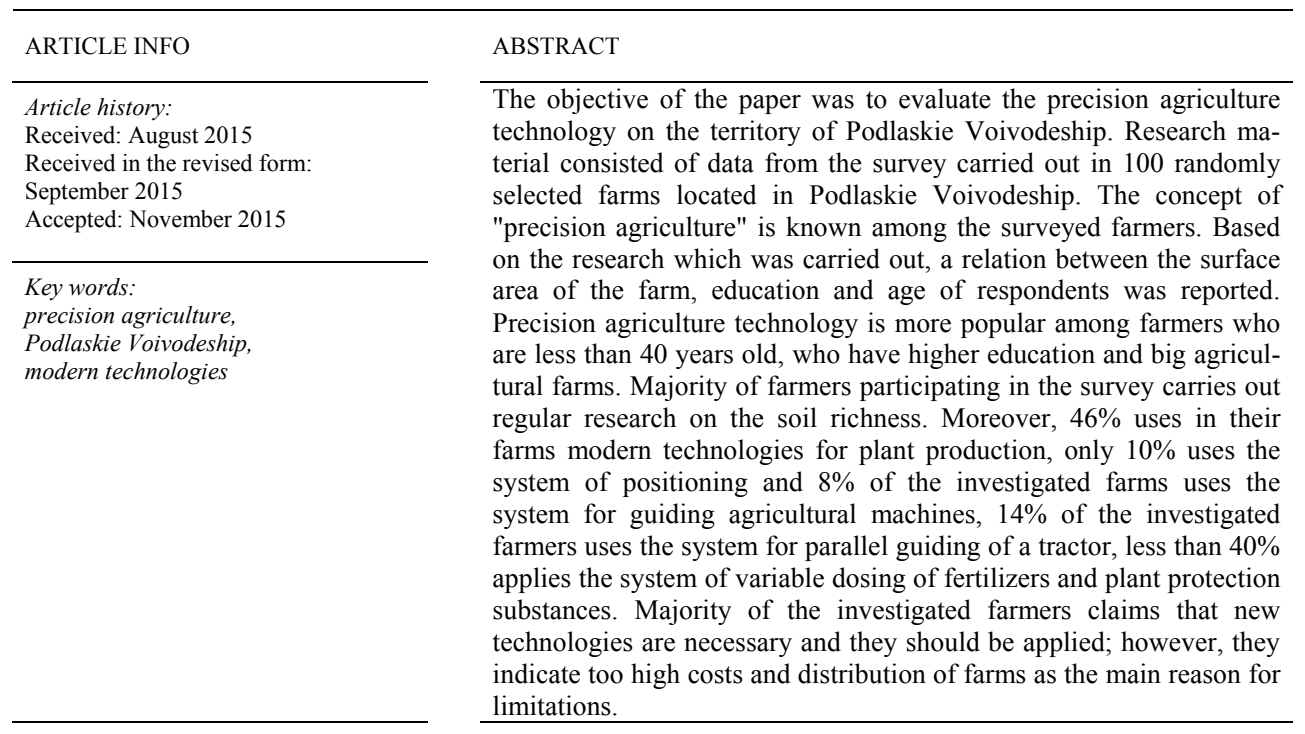

\section{Introduction}

Presently, agriculture is based to even higher extent on the professional knowledge and skills concerning information management. New technologies aiming at the increase of production efficiency and not conflicting with the sustainable development concept are implemented in order to make agricultural production profitable and competitive towards Western Europe countries. Thus, precision agriculture technology gains more popularity. It uses highly developed of navigation and IT technologies. Application of such solutions allows carrying out agricultural production in an environment friendly manner at the optimal use of production equipment and the newest technology achievement. Adjustment of all elements of agrotechnology to variable conditions, varied in space and time, on particular fields is a basic assumption of precision agriculture. Such farming enables obtaining higher 
crops at the simultaneous reduction of production costs. The most important activities related to application of the precision agriculture system consists of collecting information on the environmental variability of a given field and using these data for preparation and carrying out agrotechnology treatments adjusted to the reported variability. In the research carried out by Piskier and Mładanowicz (2003) optimization of plants fertilization with the use of the precision agriculture technology resulted in reduction of fertilization costs by $23 \%$ in comparison to the traditional system. Creation of maps with the use of GIS technology which present a detailed field contour and a variable soil richness on a given area is an indispensable condition for implementation of this system (Turowski and Kapela 2001; Gozdowski et al., 2007). Such information enables a farmer to take a decision concerning plant protection treatments, optimization of fertilization, amount of the seeds sown or the change of working parameters of cultivating machines. Combining information concerning agricultural production with a specific spatial situation gives unlimited analytical possibilities, which serve for optimization of a production cycle (Borusiewicz and Kapela 2014).

\section{Objective and scope of the study}

The objective of the paper was to evaluate the precision agriculture technology by farmers. Research material consisted of data from the survey carried out in 100 randomly selected farms which carried out animal and plant production in 2013. Farms located on the territory of Podlaskie Voivodeship were included in the research.

A survey questionnaire, which consisted of three parts, was a research instrument. The first part concerned information on the farm owner (age, education), the second information on a farm, and the third one consisted of questions relating to the precision agriculture technology, knowledge on the subject and degree of use in a farm. For the objective of the research, the following age ranges of the questioned persons were: to 30,31-40, 41-50 and more than 50 .

\section{Research results}

From among the investigated farmers, the majority age group (40\%) consisted of the persons aged 30, then farmers 41-50 years old (24\%), then farmers aged 31-40 (22\%) and the smallest group consisted of farmers aged more than $50(14 \%)$.

On account of education, the investigated group was as follows: 8 persons with professional education, 22 persons with secondary education, 18 persons with higher education and 52 persons with agricultural higher education.

The size of the investigated farms was as follows: the smallest group (6\%) consisted of farms with the surface area up to 10 ha and the most numerous groups consisted of farms with the area from 11 to 30 ha (42\%). Participation of the remaining investigated groups: $31-50$ ha, $51-70$ ha and above 70 ha were respectively: $24 \%, 18 \%$ and $10 \%$. 


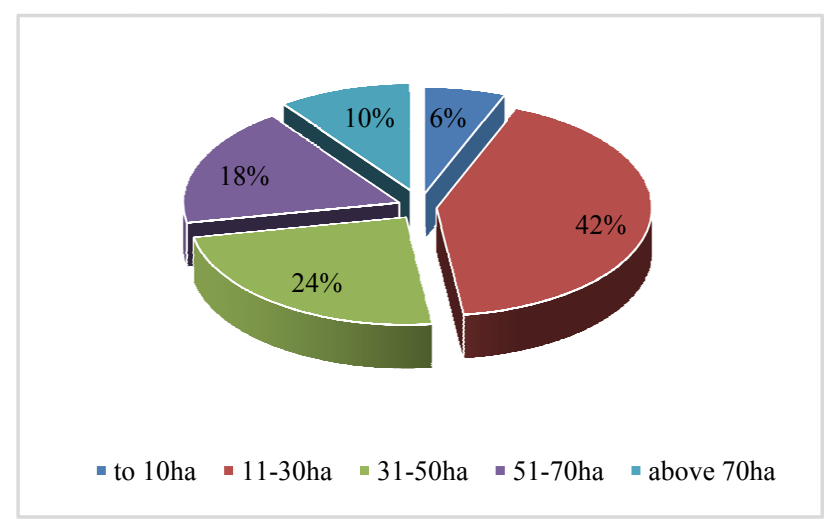

Figure 1. Area structure of agricultural land of the surveyed farms

Animal production, which is based mainly on the dairy cattle breeding, is a leading production trend among investigated farmers. Plant production is an inseparable factor of animal production. Therefore, it is also carried out in majority of investigated farms. Farms based only on plant production constitute only $6 \%$ of the total number of investigated farms and these are mainly farms whose surface is less than 10 ha.

Majority of farmers know the concept of precision agriculture. Owners of farms with the area above 10 ha and farmers with higher education are more aware. It is related to getting knowledge on such technologies at the academic level. In farms below 10 ha and among the age group above 50 years of age, a decisive majority of the surveyed people did not know the term "precision agriculture".

$64 \%$ of the investigated farmers claim that new technologies are necessary and they should be applied; however, they indicate too high costs and distribution of farms as the main reasons for limitation in using precision agriculture.

Results show that majority of farmers who take part in the research $(78 \%)$ carries out soil richness research. However, the content of nutrients within one field may change on small distances. As the research showed (Usowicz et al., 2004), a great number of samples is required at the stage of recognizing soil properties. It is directly related to the increased costs, which may constitute a direct reason for farmers' resignation from soil tests. Among the investigated farmers, $22 \%$ do not investigate the soil. However, also among persons who carry out soil tests and create maps of soil richness in nutrients, the obtained information is no longer used. On their basis, a diary of fields with the use of GIS software may be created. Data stored in such manner will allow current calculation of efficiency of particular treatments. Information obtained from farmers proves that any of the farmers who participate in the research do not create soil richness maps in their farm, although a decisive majority of these farmers carried out soil tests. A possible reason for such state of things is lack of agricultural software or lack of knowledge on issues concerning the Geographic Information System.

The research showed that $46 \%$ of the surveyed persons applied modern technologies for plant production in their farms. Positioning is an example of the precise agricultural element. It is very significant because reliable mapping of a yield or soil variability requires 
precise positioning to $1 \mathrm{~mm}$ and less and for precise treatments of weed killing and microspraying a precision must be even higher. However, despite undoubted advantages of this system, only $10 \%$ of the investigated persons use the positioning system and $8 \%$ use the system of guiding agricultural machines. $14 \%$ of the investigated farmers use the system of parallel driving of a tractor and $40 \%$ use the system of variable dosing of fertilizers and crop protection substances.

Table 1

Participation of precision agriculture systems in the surveyed farms (in \%)

\begin{tabular}{lcc}
\hline Precise agriculture system & YES & NO \\
\hline Positioning of machines & 10 & 90 \\
\hline Machine guiding & 8 & 92 \\
\hline Parallel driving/running of machines & 14 & 86 \\
\hline Variable dosing & 40 & 60 \\
\hline
\end{tabular}

The use of parallel navigation with the use of GPS is material for maintaining precise fertilization, spraying or sowing of seeds in a traditional manner. It allows operation of a machine on parallel routes guaranteeing evenness regardless the conditions and the lie of a field. GIS systems used for this purpose are present in many branches of Polish economy, mainly in geodesy, forestry and environment protection. They also can be successfully used in agriculture and give unlimited analytical possibilities. However, $100 \%$ of respondents answered negatively to the question "Do you use GIS technologies in your farm?"

Physical and chemical properties of soil are very significant from the agricultural point of view. Usually farmers in field production limit their activities to testing soil richness in basic macroelements and $\mathrm{pH}$ marking. Assessment of the remaining soil properties, mainly on account of a higher price of analysis is often omitted (Gozdowski et al., 2007). Using optimized fertilization on account of date, type and dose is one of the most important elements of precision agriculture in plant production (Jadczyszyn, 1998). At rising prices of fertilizers, optimization of fertilization may bring notable financial savings. Quite frequently, the amount of the used fertilizer in the variable dosing technology may be similar to the traditional system but the production potential of particular parts of a field is better used (Doruchowski, 2008). The research also showed that dosing of many or a single lacking component on the entire area of the investigated field without previous creation of richness maps often happens.

Presently, plant protection is based mainly on using pesticides. These substances despite a limited toxicity often have a negative impact on environment. Using plant protection substances in precise agriculture consists in identification of plant infestation on a plantation, determination of the type, degree of intensification and place where pests occur and then preparing a map of variable application of plant protection substances. The prepared map allows the use of a suitable substance in a relevant place and with relevant intensification so that its amount is the least possible and applied only where it is required. Such methods are work consuming and difficult to be applied in a short time. However, the use of 
Application of precision agriculture...

this system may reduce the production costs through reduction of herbicides consumption even by 50-75\% (Pedersen et al., 2004).

The following unused solution among the surveyed persons consists of programmes for farm managing such as "Agrar-Office". They enable obtaining information on application of fertilizer doses in a short time, development of the fertilization schedule, balance of nutrients, fast planning and proper reaction, transferring work to a machine, fast calculation of incurred costs and production profitability. The obtained information shows that for the investigated farmers the use of this type of programs is an insignificant factor in plant production. All surveyed farmers answered negatively to the following question: "Do you create a field diary with the use of software that facilitates farm management".

Although precision agriculture technologies are presently quite innovative for the surveyed, the majority (64\%) of them answered that they are necessary. Only $10 \%$ of them claims that they are unnecessary: in this group people who are more than 50 years old prevailed. The remaining questioned people stated that such technologies are useful but not necessary. Small area of land is for the investigated farmers most vital in implementation of new technologies. High investment cost is the second important problem indicated by the surveyed farmers.

\section{Discussion}

Technical progress which takes place in agriculture consists in: the efficiency increase, improvement of reliability and increase of the operation quality of machines. Implementation of precision agriculture systems in farms causes reduction of material consumption and energy consumption of production, mainly of plant production and thus improves production efficiency and reduction of environmental threats (Doruchowski, 2008).

In recent years a significant progress took place in the satellite navigation field, variable dosing of fertilizers and yield mapping. In order to face the challenge of introducing the precise farming system one should reach for GIS Technologies - efficient tool for integration of agricultural research. Information concerning agricultural production combined with a specific spatial situation gives unlimited analytical possibilities which serve for optimization of a production cycle. Thanks to this we obtain a tool, which affects the improvement of the quality and efficiency of work (Zbytek and Młodanowicz, 2001; Bobola and Sztampke, 2008).

Despite the undoubted advantages of using precision agriculture technologies, they have not been sufficiently known and used by the surveyed farm owners.

One of the factors, which may affect the above, is that animal production with prevailing dairy cattle breeding is a dominant production trend on the territory of Podlaskie Voivodeship. In the recent 20 years, a considerable modernization of animal production has taken place e.g. computer controlled equipment of cowsheds, milking operations, etc. (Borusiewicz et al., 2015). Considerable investments in this field caused much lower interest in modern technologies in plant production not related to production of fodder for animals.

Presently, distribution of farms is a great impediment for introduction of modern technologies which is related to economic aspects. Purchase of machines and devices is possible in many cases only in large-area farms. These farms have great acreage and the eco- 
nomic and quality effect of these farms is visible on account of the production scale (Gozdowski, 2007).

Moreover, implementation of innovative technologies requires from the farmer to be open to such solutions. Fear of using modern systems of precise agriculture may be caused by economic profitability which is difficult to prove.

Introduction of precision agriculture systems in farms requires farmers to know the subject, to update their knowledge and to systemically extend it, to rationally evaluate their own actions and to learn by mistakes; also their implementation without suitable knowledge and qualifications in their application will not bring expected results. The condition for the success is mainly a skill to learn by mistakes, critical evaluation of own activities, intellectual effort and being involved (Gaultney, 2008; Stafford, 2007; Zalewski, 2000). Regardless the scale on which precision agriculture technologies are presently used in practice, further research and popularization of information related thereto are necessary because this field of knowledge develops dynamically and in many directions (McBratney et al., 2005).

\section{Conclusions}

1. Precision agriculture technologies are still an innovative system of carrying out agricultural activity in Podlaskie Voivodeship.

2. Although, majority of farmers know the concept of precision agriculture they do not show their interest in using this technology in their farms.

3. The area of land is the most important precondition which decides on implementation of new technologies to a farm. It translates into higher production costs, limited efficiency and lower competitiveness. Only $10 \%$ of farmers use the positioning system and only $8 \%$ of the surveyed farmers apply the system for guiding agricultural machines. $14 \%$ of the investigated farmers use the system of parallel guiding.

4. A high investment cost of computer equipment, software and executive devices in the second problem indicated by farmers.

5. No openness to innovations, particularly concerning plant production is a significant issue.

6. Farmers' awareness concerning the use of precision agriculture technologies increases along with the education level. Farmers with higher education have a greater knowledge in this subject.

\section{References}

Bobola, G., Sztampke, M. (2008). Zastosowanie systemów informacji przestrzennej w rolnictwie. Inżynieria Rolnicza, 11(109), 7-15.

Borusiewicz, A., Drożyner P., Marczuk T. (2015). Zmiany stanu wyposażenia gospodarstw rolnych w środki mechanizacji stosowane w produkcji mleka. Problemy Inżynierii Rolniczej, 1(87), 69-77.

Borusiewicz, A., Kapela, K. (2014). Wdrożenie technik rolnictwa precyzyjnego na przykładzie wielkopowierzchniowego gospodarstwa rolnego. Inżynieria Rolnicza, 2(150), 31-37.

Doruchowski, G. (2008). Postęp i nowe koncepcje w rolnictwie precyzyjnym. Inżynieria Rolnicza, 9(107), 19-21. 
Application of precision agriculture...

Gaultney, L. (2008). Economic and environmental benefits of precision agriculture in fruit and vegetable production. Book of Abstracts: International Symposium - Precision Agriculture for Fruits and Vegetables. Orlando. 6-9.01.2008.

Gozdowski, D., Samborski, S., Sioma, S. (2007). Rolnictwo precyzyjne. Wydawnictwo SGGW.

Warszawa. ISBN 978-83-7244-858-3.

Jadczyszyn, T. (1998). System Rolnictwa Precyzyjnego. III. Nawożenie w rolnictwie precyzyjnym. Frag. Agron., 1(57), 28-40.

McBratney, A., Whelan, B., Ancev, T., Bouma, J. (2005). Future directions for fungal plant pathogens. Pest Management Science, 59.129-142.

Pedersen, S.M., Fountas, S., Blackmore, B.S., Gylling, M., Pedersen, J.L. (2004). Adoption and perspectives of precision farming in Denmark. Acta Agriculturae Scandinavica, Section B-Soil \& Plant Science, 54, 4-8.

Piskier, T., Mładanowicz, R. (2003). Efektywność nawożenia mineralnego w rolnictwie precyzyjnym. Inżynieria Rolnicza, 10(52), 221-227.

Stafford, J. A. (2007). Briew History of Precision Agriculture. Book of Abstracts: $2^{\text {nd }}$ Conference on Precision Crop Protection. Bonn, 10-12.10.2007.

Turowski, J., Kapela, K. (2001). Możliwość wykorzystywania globalnego systemu pozycjonowania w rolnictwie. Inżynieria Rolnicza, 1(21), 333-338.

Usowicz B., Hajnos, M., Sokołowska, Z., Józefaciuk, G., Kossowski, J. (2004). Przestrzenna zmienność fizycznych i chemicznych właściwości gleby w skali pola i gminy. Acta Agrophysica,103(3), $1-98$.

Zalewski, P. (2000). Problemy rolnictwa precyzyjnego. Inżynieria Rolnicza,8(19), 15-23.

Zbytek, Z., Młodanowicz, R. (2001). Zastosowanie zasad rolnictwa precyzyjnego w Polsce. Journal of Research and Applications in Agriculture and Engineering,46(4), 60-67.

\section{WYKORZYSTANIE TECHNOLOGII ROLNICTWA PRECYZYJNEGO NA TERENIE WOJEWÓDZTWA PODLASKIEGO}

Streszczenie. Celem badań była ocena stopnia wykorzystania technologii rolnictwa precyzyjnego na terenie województwa podlaskiego. Materiał badawczy stanowiły dane pochodzące $\mathrm{z}$ badań ankietowych przeprowadzonych wśród 100 losowo wybranych gospodarstw rolnych, położonych na terenie województwa podlaskiego. Spośród badanych rolników większości znane jest pojęcie „rolnictwa precyzyjnego". Na podstawie przeprowadzonych badań zauważono związek między powierzchnią gospodarstwa, wykształceniem i wiekiem respondentów. Technologia rolnictwa precyzyjnego bardziej znana jest wśród rolników w wieku do 40 lat, którzy posiadają wyższe wykształcenie oraz duże gospodarstwa rolne. Większość rolników biorących udział w badaniu przeprowadza regularnie badania zasobności gleb. Ponadto: $46 \%$ wykorzystuje w swoim gospodarstwie nowoczesne technologie w produkcji roślinnej, systemu pozycjonowania używa zaledwie $10 \%$ a naprowadzania maszyn rolniczych $8 \%$ badanych gospodarstw, system prowadzenia równoległego ciągnika wykorzystuje $14 \%$ badanych rolników, niecałe $40 \%$ stosuje system zmiennego dawkowania nawozów oraz środków ochrony roślin. Większość badanych rolników uważa, że nowe technologie są potrzebne i należy z nich korzystać, jednak jako główny powód ograniczenia wskazują zbyt wysokie koszty oraz rozdrobnienie gospodarstw.

Słowa kluczowe: rolnictwo precyzyjne, województwo podlaskie, nowoczesne technologie 